\title{
Cadcam: A Perspective of Dental Undergraduate
}

\author{
${ }^{1}$ Kavarthapu. Avinash, ${ }^{2}$ Dr. Suresh.V, M.D.S., \\ ${ }^{1}$ B.D.S. Saveetha Dental College and Hospital, Chennai. \\ ${ }^{2}$ Saveetha Dental College and Hospital, Chennai.
}

\begin{abstract}
:
Background: Computer science has evolved into the field of dentistry many years ago. Newer addition is CADCAM. In this study we assessed the knowledge of dental undergraduate in Chennai towards the technology and mechanics of CADCAM.

Methods: In this study we considered 600 undergraduate students in studying in different institutions in Chennai to participate in a questionnaire survey on knowledge of CADCAM. Pearson Chi square test was used for analysis. The students were categorised into 3 groups namely Interns, Final years and Third years.

Results: 525 responders were considered valid for analysis. The level of knowledge was significantly higher in Interns ( $p$ <0.001). Moreover the knowledge and awareness of CADCAM has improved with the increase in grade.

Conclusions: This study shows that the theoretical knowledge is not transformed into practical situation and an interdisciplinary approach between dental and engineering students may attain a better knowledge towards the mechanics and usage of CADCAM.
\end{abstract}

Keywords: CADCAM, Questionnaire study, undergraduate dental students, History.

\section{Introduction}

The crave for better needs creates the newer technology. CADCAM is the recent addition to the field of dentistry. Accuracy and less time for fabricationpromises the future of CADCAM. The CADCAM system has created a wide spread awareness among the dental undergraduates worldwide denoting an increase of usage in future.

Dentistry has a long well documented history for contributing to the rehabilitation of oral function by offering prosthetic devices like inlay, onlay, crowns, Fixed Partial Denture(FPD), Removable Partial Denture(RPD) etc., ${ }^{[1,2]}$ It is estimated that in 2007, more than 33 million crowns, 10 million bridges, and 3 million veneers were provided to patientsin the United States. ${ }^{[3]}$ Inlays represent a very small portion of allfixed restorations, an estimated $3 \%$ in $1999 .{ }^{[4]}$

The introduction of CAD/CAM to dentistry took place during the 1980 s. ${ }^{[5]}$ The first CAD/CAM devices introduced were CEREC (Sirona) and Procera(Nobel Biocare). CEREC was originally introduced strictly as a chairside technique; the objective was to perform a one-visit procedure for fixed restorations, with a focus on the provision of inlays and onlay`s. ${ }^{[6]}$ Since then the acceptance rate for the dental prostheses among the patients has been increased which results in the development of new high strength ceramics. ${ }^{[7]}$

Three authors Dr.Duret, Dr.Moermann and Dr.Anderson contributed to the development of CADCAM in dentistry ${ }^{[8]}$ Dr.Duret was the first one who started with an optical impression of abutment teeth. ${ }^{\left[{ }^{8]}\right.}$ Dr.Moermann was the second one who developed chair side CADCAM. Dr.Anderson was the third one who attempted to fabricate titanium copings by spark erosion and introduced CADCAM technology into the process of composite veneered restorations. ${ }^{[9]}$

CADCAM has come since its inception, the technology and engineering miracles has captured every young mind. During the literature season there was a lacunae if the dental undergraduates were able to understand the technology behind the CADCAM. Hence the present study was designed to identify the short coming of dental undergraduates.

\section{Materials And Methods}

A self-explanatory questionnaire was distributed randomly among dental undergraduates in Chennai. No demographic data was taken, only their year of study was asked. The questionnaire was designed to access the type of materials used, digital impression, future of CADCAM in dentistry etc., Statistical analysis was done usingPearson Chi square test. 


\section{Questionnaire Design}

1. Do u know led light is used to make an impression??
A)yes
b)no
c)may be
d)don't know

2 .Do u think optical spray is needed for making digital impression??
A)always
b)never c)sometimes
d)don't know

3. Have you ever seen cad-cam machine??

A)yes b)no c)never heard of it d)never got a chance

4 .Have you seen a CADCAM milled crown??
A)yes b)no
c)not sure
d)don't know

5 .How long does CADCAM takes for milling a single crown??
A) <hour
b) 2 hours
c) 3 hours
d)4 hours

6. Do u know that CADCAM blocks has shrinkage factor???
A)yes b)no
c)may be
d)don't know

7. Materials used in CADCAM includes.

A)waxesb)metals c)zirconia d)all the above

8. Can post and core be done using CADCAM???
A)yes
b)no
c)may be
d)don't know

9 .Have you ever planned a CADCAM crown for your patient???
A)yes
b)no
c) haven't replaced a tooth
d)not worthy

10. If not, what made you from not advisingCADCAM crown???

A)high cost b)facility unavailable c)not heard of cad cam crown

D)never treated a patient who needs crown

11. Were you taught about CADCAM in your institution?
A)yes
b)no
c)partly d)don't know

12. Do you know the difference between stained crown and layered crown??
A)yes
b)no
c)don't know

13. Do you think CADCAM plays an important role in future dentistry??
A)yes
b)no
c)may be
d)don't know

Thanks for your cooperation

\section{Results}

\section{Response and data availability}

Of the600 questionnaire distributed, only 540 has been received back and only 525 were considered valid. The study was divided into 3 groups based on the year of study and the questionnaires were distributed equally to 3 groups namely third years, final years and interns.

\section{Knowledge of mechanics}

Four questions were asked to assess the knowledge of mechanics of CADCAM. The results shows remarkably better knowledge to interns followed by final years and third years respectively while the $p<0.001$ (Table 1)

Table:1

\begin{tabular}{|c|c|c|c|c|c|c|c|c|c|c|c|}
\hline \multirow{2}{*}{$\begin{array}{l}\text { Question } \\
\text { (correct response) }\end{array}$} & \multirow[t]{2}{*}{ Total\% } & \multicolumn{3}{|c|}{ Interns } & \multicolumn{3}{|c|}{ Final years } & \multicolumn{3}{|c|}{ Third years } & \multirow{2}{*}{$\begin{array}{l}\mathbf{P} \\
\text { valu } \\
\text { e }\end{array}$} \\
\hline & & $\begin{array}{l}\text { Cou } \\
\text { nt }\end{array}$ & $\begin{array}{l}\text { \%wit } \\
\text { h- in } \\
\text { group }\end{array}$ & $\begin{array}{l}\% \text { of } \\
\text { total }\end{array}$ & $\begin{array}{l}\text { Cou } \\
\text { nt }\end{array}$ & $\begin{array}{l}\text { \%wit } \\
\text { h } \quad \text {-in } \\
\text { group }\end{array}$ & $\begin{array}{l}\% \\
\text { of } \\
\text { tota } \\
1\end{array}$ & $\begin{array}{l}\text { Cou } \\
\text { nt }\end{array}$ & $\begin{array}{l}\text { \%wit } \\
\text { h- in } \\
\text { group }\end{array}$ & $\begin{array}{l}\% \\
\text { of } \\
\text { tota } \\
1\end{array}$ & \\
\hline $\begin{array}{l}\text { Do u know led light is } \\
\text { used to make an } \\
\text { impression??(yes) }\end{array}$ & 25.7 & 65 & 37.10 & 12.40 & 37 & 21.10 & 7.00 & 33 & 18.90 & 6.30 & $\begin{array}{l}<0.0 \\
01\end{array}$ \\
\hline $\begin{array}{l}\text { Do u think optical spray } \\
\text { is needed for making } \\
\text { digital impression?? (yes) }\end{array}$ & 14.10 & 44 & 25.10 & 8.40 & 18 & 10.30 & 3.40 & 12 & 6.90 & 2.30 & $\begin{array}{l}<0.0 \\
01\end{array}$ \\
\hline $\begin{array}{lrr}\text { How long } & \text { does } \\
\text { CADCAM } \quad \text { takes } & \text { for } \\
\text { milling a } & \text { single } \\
\text { crown??(< hour }) & \\
\end{array}$ & 45 & 106 & 60.6 & 20.2 & 72 & 41.1 & 13.7 & 58 & 33.1 & 11.0 & $\begin{array}{l}<0.0 \\
01\end{array}$ \\
\hline $\begin{array}{l}\text { Materials used in } \\
\text { CADCAM includes..(All) }\end{array}$ & 36.2 & 60 & 34.3 & 11.4 & 60 & 34.3 & 11.4 & 70 & 40.0 & 13.3 & $\begin{array}{l}<0.0 \\
01\end{array}$ \\
\hline
\end{tabular}

$\mathbf{P}<\mathbf{0 . 0 0 1}$; highly significant after multiple test correction 
Attitude towards machine and usage

The results are highly significant $(\mathrm{p}<0.001)$ on have you ever seen a CADCAM machine and CADCAM milled crown.Analysis to a question planning of a CADCAM crown to your patient also gives a significant result $(\mathrm{p}<0.001)($ table 2$)$

Table:2

\begin{tabular}{|c|c|c|c|c|c|c|c|c|c|c|c|}
\hline \multirow{2}{*}{$\begin{array}{l}\text { Question } \\
\text { (correct response) }\end{array}$} & \multirow{2}{*}{$\begin{array}{l}\text { Total } \\
\%\end{array}$} & \multicolumn{3}{|l|}{ Interns } & \multicolumn{3}{|c|}{ Final years } & \multicolumn{3}{|c|}{ Third years } & \multirow{2}{*}{$\begin{array}{l}\mathbf{P} \\
\text { value }\end{array}$} \\
\hline & & Count & $\begin{array}{l}\text { \%with- } \\
\text { in group }\end{array}$ & $\begin{array}{l}\% \text { of } \\
\text { total }\end{array}$ & Count & $\begin{array}{l}\text { \%with } \\
\text {-in } \\
\text { group }\end{array}$ & $\begin{array}{l}\% \\
\text { of } \\
\text { total }\end{array}$ & $\begin{array}{l}\text { Coun } \\
t\end{array}$ & $\begin{array}{l}\text { \%with } \\
-\quad \text { in } \\
\text { group }\end{array}$ & $\begin{array}{l}\% \text { of } \\
\text { total }\end{array}$ & \\
\hline $\begin{array}{l}\text { Have you ever seen } \\
\text { cad-cam machine??? }\end{array}$ & 50.1 & 104 & 59.4 & 19.8 & 87 & 39.7 & 16.6 & 72 & 41.1 & 13.7 & $\begin{array}{l}<0.00 \\
1\end{array}$ \\
\hline $\begin{array}{lr}\text { Have you seen a } \\
\text { CADCAM milled } \\
\text { crown?? (yes) }\end{array}$ & 38.1 & 96 & 54.9 & 18.3 & 54 & 30.9 & 10.3 & 50 & 28.6 & 9.5 & $\begin{array}{l}<0.00 \\
1\end{array}$ \\
\hline $\begin{array}{l}\text { Have you ever planned } \\
\text { a CADCAM crown for } \\
\text { your patient??? }\end{array}$ & 22.3 & 58 & 33.1 & 11.0 & 38 & 21.7 & 7.2 & 21 & 12.0 & 4.0 & $\begin{array}{l}<0.00 \\
1\end{array}$ \\
\hline
\end{tabular}

$\mathbf{P}<\mathbf{0 . 0 0 1}$; highly significant after multiple test correction

\section{Attitude towards teaching and future of CADCAM}

It is interesting to note that our data gave a $\mathrm{p}$ value of $<0.004$ to CADCAM blocks has shrinkage factor and the difference between stained crown and layered crown.However the $\mathrm{p}$ value was highly significant to the rest of the questions asked. (Table 3)

Table:3

\begin{tabular}{|c|c|c|c|c|c|c|c|c|c|c|c|}
\hline \multirow{2}{*}{$\begin{array}{l}\text { Question } \\
\text { (correct response) }\end{array}$} & \multirow{2}{*}{$\begin{array}{l}\text { Total } \\
\%\end{array}$} & \multicolumn{3}{|c|}{ Interns } & \multicolumn{3}{|c|}{ Final years } & \multicolumn{3}{|c|}{ Third years } & \multirow{2}{*}{$\begin{array}{l}P \\
\text { value }\end{array}$} \\
\hline & & Count & $\begin{array}{l}\text { \%with } \\
\text {-in } \\
\text { group }\end{array}$ & $\begin{array}{l}\% \\
\text { of } \\
\text { tota } \\
1\end{array}$ & Count & $\begin{array}{l}\text { \%wit } \\
\text { h-in } \\
\text { group }\end{array}$ & $\begin{array}{l}\text { \% } \\
\text { of } \\
\text { total }\end{array}$ & $\begin{array}{l}\text { Coun } \\
t\end{array}$ & $\begin{array}{l}\text { \%wit } \\
\text { h- in } \\
\text { group }\end{array}$ & $\begin{array}{l}\% \\
\text { of } \\
\text { total }\end{array}$ & \\
\hline $\begin{array}{l}\text { Were you taught } \\
\text { about CADCAM in } \\
\text { your } \\
\text { institution?(yes) }\end{array}$ & 40.2 & 91 & 52.0 & $\begin{array}{l}17 . \\
3\end{array}$ & 66 & 37.7 & 12.6 & 54 & 30.9 & 10.3 & $\begin{array}{l}<0.00 \\
1\end{array}$ \\
\hline $\begin{array}{l}\text { Do u know that } \\
\text { CADCAM blocks } \\
\text { has shrinkage } \\
\text { factor??? (yes) }\end{array}$ & 11.4 & 33 & 18.9 & 6.3 & 19 & 10.9 & 3.6 & 8 & 4.6 & 1.5 & $\begin{array}{l}<0.00 \\
4\end{array}$ \\
\hline $\begin{array}{l}\text { Can post and core be } \\
\text { doner using } \\
\text { CADCAM???(YES) }\end{array}$ & 16.2 & 43 & 24.6 & 8.2 & 23 & 13.1 & 4.4 & 19 & 10.9 & 3.6 & $\begin{array}{l}<0.00 \\
1\end{array}$ \\
\hline $\begin{array}{l}\text { Do you know the } \\
\text { difference between } \\
\text { stained crown and } \\
\text { layered } \\
\text { crown??(YES) }\end{array}$ & 17.0 & 42 & 24.0 & 8.0 & 31 & 17.7 & 5.9 & 16 & 9.1 & 3.0 & $\begin{array}{l}<0.00 \\
4\end{array}$ \\
\hline $\begin{array}{l}\text { Do you think } \\
\text { CADCAM plays an } \\
\text { important role in } \\
\text { future dentistry?? }\end{array}$ & 64.8 & 127 & 72.6 & $\begin{array}{l}24 . \\
2\end{array}$ & 96 & 54.9 & 18.3 & 117 & 66.9 & 22.3 & $\begin{array}{l}<0.00 \\
1\end{array}$ \\
\hline
\end{tabular}

$\mathbf{P}<\mathbf{0 . 0 0 5}$; significant after multiple test correction

\section{Discussion}

With the amount of medical information doubling every year, it is obvious that education will be increasingly dependent on information technology to enable teachers and learners to cope with the growing amountof information necessary to keep up-to-date in this field. ${ }^{[10]}$ Mapping the development, this study was designed to assess the knowledge of newer technology and its mechanics into the field of dentistry. Some similarity can be drawn from a study in china by Huang et al on knowledge, attitude and practice of antibiotics highlights that china medical curriculum improves students knowledge of usage of antibiotics appropriately. ${ }^{[1]}$ The knowledge of functioning and mechanism of surface details capturing and the use of LED lights were unknown to $40 \%$ of third years and $38.9 \%$ of final years. The use of optical spray for digital impression was unknown to $54.9 \%$ and $43.4 \%$ of third year and finals year students respectively. Among the undergraduate 
students, only $59 \%$ of intern has seen a CADCAM machine and $34 \%$ of them had never got a chance and the percentage seems to be much lower $(\mathrm{p}<0.001)$ for have they seen milled CADCAM crown.

Shrinkage factor plays a major role in the fit of the CADCAM crown. ${ }^{[12]}$ Shrinkage factor is defined as the percentage short fall of a planned output amount. The CADCAM blocks are manufactured in various sizes. Each bar has a density barcode label, so the copy mill machine can be adjusted properly to allow for shrinkage during the shrinkage phase ${ }^{[13]}$ Details of CADCAM blocks shrinkage factor, meaning of stained crown and layered crown and the duration of milling in which it shows the knowledge in this particular prospective was seemed to be lowest among all the three groups including the interns. The interns recorded a knowledge about shrinkage factor among the sample size was only $18.9 \%$.

Even the knowledge about post and core construction using CADCAM technology among the interns was very less and $23.7 \%$ of total sample size sure about the post and core construction using CADCAM. The usage of CADCAM crown $t$ Dr. Rashmi chouro their patients was very less and the reason behind it was said to be due to unavailability of CADCAM machine in their institution.

Mechanism and use of CADCAM was taught to $40.2 \%$ of the total sample size and $64.8 \%$ knows that the future is in the hands of CADCAM. This lag in the knowledge of mechanics is because of the theoretical knowledge about it couldn't be transferred to practical situation. The reason behind it to be of orally taught and not exposing directly to the machine at an undergraduate level. Some similarity is drawn from the study done byBergman et al on students perceptions of anatomy acrossthe undergraduate problem based medical curriculum highlighted that rewarding understanding higher order cognitive skills are required to improve education. ${ }^{[14]}$

Detailed knowledge about calculating the shrinkage factor and technology used was insufficient in dental curriculum. According to Nkenke et al biomedical knowledge and technology should go hand in hand. ${ }^{[10]}$

Since many of the undergraduate students agreed the future is CADCAM,interaction about functioning of capturing details, the robotic sciences might need to be of interdisciplinary approach.

\section{Conclusion}

The study was designed to understand the knowledge and attitude of dental undergraduates towards CADCAM. This study definitely inclined and indicates that CADCAM milled crown is going to be the future or replaces the conventional metal ceramic crowns. At the same time the students lack in-depth knowledge about the construction and machining process of CADCAM. If the students bridge the theory and the practical aspects, they eventually maser in the field leading to a brighter CADCAM future. An interdisciplinary group or discussion or research among the dental undergraduate and the engineering students should be initiated that can even help in construction of an indigenous Indian made CADCAM machine.

\section{References:}

[1] Icons of dentistry: Dr Leon Eisnebud: J.Oral Implantology, 2006;32(2):53-4

[2] Miyazaki.T, Hotta Y, Suzuki E, Miyaji T, Takahashi H, Funya., Kawawa J. An approach to dental CAD/CAM using the electric discharge machining(part1) measurement coronal figure, computer graphics and CAD procedure. J.Shova Univ Dent Soc 1991;11:65-69.

[3] Data Research Inc., 2007, U.S. Market for Dental ProstheticDevices.

[4] American Dental Association. The 1999 Survey of Denta Services Rendered.

[5] Calamia JR. Advances in computer-aided design andcomputer-aided manufacture technology. Curr OpinCosmet Dent. 1994:67-73.

[6] Giordano R. Materials for chairside CAD/CAM-producedrestorations. J Am Dent Assoc. 2006 Sep;137 Suppl:14S-21S.

[7] Shanghai Kou Qiang Yi Xui. The history and clinical application of chairside CADCAM dental restoration system.2006 oct;15(5):449-55

[8] Miyazaki T, Hotta Y, Kunii J, Kuriyama S,Tamaki Y. A review of dental CAD/CAM:current status and future perspectivesfrom 20 years of experience. Dent Mater J 2009;28:44-56.

[9] Daniel J. Poticny and James Klim; CAD/CAM In-office Technology: Innovations After 25 years for predictable, Esthetic Outcomes. JADA 2010;141(suppl 2):5S-9S.

[10] Nkenke et al. Acceptance of technology-enhanced learning for a theoretical radiological science course: a randomized controlled trail; BMC medical Education 201212:18

[11] Huang Jiarui Gu et al. Knowledge, attitude and practice of antibiotics:

[12] a questionnaire study among 2500 Chinese students;BMC Medical Education 2013,13:163-172.

[13] Jeong-Yol Lee et al, Effect of span length on the fit of zirconia framework fabricated using CAD/CAM system: J Adv Prosthodont 2013;5:118-25

[14] Gregg A. Helvey, Zirconia and Computer-aided Design/Computer-aided Manufacturing (CAD/CAM) Dentistry: Inside Dentistry; April 2008, Volume 4, Issue 4.

[15] Bergman et al. Students' perceptions of anatomy across theundergraduate problem-based learning medical

[16] curriculum: a phenomenographical study. BMC Medical Education 2013, 13:152. 